\title{
Enhanced Medical and Community Face Masks with Antimicrobial Properties: A Systematic Review
}

\author{
Katy Stokes ${ }^{1}$, Roberto Peltrini ${ }^{2}(0)$, Umberto Bracale ${ }^{3}$, Marcella Trombetta ${ }^{4}$, Leandro Pecchia ${ }^{1, *}$ \\ and Francesco Basoli $4, *$ (D) \\ 1 School of Engineering, University of Warwick, Coventry CV4 7AL, UK; Katy.Stokes@warwick.ac.uk \\ 2 Department of Public Health, Federico II University Hospital, 80131 Naples, Italy; roberto.peltrini@gmail.com \\ 3 Department of Advanced Biomedical Sciences, Federico II University Hospital, 80131 Naples, Italy; \\ umbertobracale@gmail.com \\ 4 Department of Engineering, University Campus Bio-Medico di Roma, 00128 Rome, Italy; \\ m.trombetta@unicampus.it \\ * Correspondence: L.Pecchia@warwick.ac.uk (L.P.); f.basoli@unicampus.it (F.B.)
}

Citation: Stokes, K.; Peltrini, R.; Bracale, U.; Trombetta, M.; Pecchia, L.; Basoli, F. Enhanced Medical and Community Face Masks with Antimicrobial Properties: A Systematic Review. J. Clin. Med. 2021, 10, 4066. https://doi.org/10.3390/ jcm10184066

Academic Editor: Barbara Zavan

Received: 4 August 2021

Accepted: 7 September 2021

Published: 9 September 2021

Publisher's Note: MDPI stays neutral with regard to jurisdictional claims in published maps and institutional affiliations.

Copyright: (c) 2021 by the authors. Licensee MDPI, Basel, Switzerland. This article is an open access article distributed under the terms and conditions of the Creative Commons Attribution (CC BY) license (https:// creativecommons.org/licenses/by/ $4.0 /)$.

\begin{abstract}
Face masks help to limit transmission of infectious diseases entering through the nose and mouth. Beyond reprocessing and decontamination, antimicrobial treatments could extend the lifetime of face masks whilst also further reducing the chance of disease transmission. Here, we review the efficacy of treatments pertaining antimicrobial properties to medical face masks, filtering facepiece respirators and non-medical face masks. Searching databases identified 2113 studies after de-duplication. A total of 17 relevant studies were included in the qualitative synthesis. Risk of bias was found to be moderate or low in all cases. Sixteen articles demonstrated success in avoiding proliferation (if not elimination) of viruses and/or bacteria. In terms of methodology, no two articles employed identical approaches to efficacy testing. Our findings highlight that antimicrobial treatment is a promising route to extending the life and improving the safety of face masks. In order to reach significant achievements, shared and precise methodology and reporting is needed.
\end{abstract}

Keywords: antimicrobial; personal protective equipment; face masks; filtering facepiece respirator; COVID-19; pandemic

\section{Introduction}

The present pandemic due to coronavirus disease (COVID-19) significantly impacted the health of millions of people and highlighted weaknesses in the personal protective equipment (PPE) supply chain around the world. Face masks have been used in medical settings for infection prevention for decades, being one of the most important countermeasures in mitigating high risk of droplet and aerosol transmission of pathogens in health care settings [1]. Medical masks and FFP2 or N95 respirators are recommended for Health Workers (HWs) when providing care to suspected or confirmed COVID-19 patients, especially if performing aerosol generating procedures, which requires respirators to be worn continuously [2]. Patients must wear medical face masks for in person care to control sources of infection [3]. Expanded use of masks has resulted in increased wear time and use without training. Although there is precedent for mask wearing among the general public in Asian countries such as China, South Korea and Japan, this only became a global strategy in reaction to the spread of severe acute respiratory syndrome coronavirus 2 (SARS-CoV-2). Mask wearing is generally considered a low risk and low-cost approach for disease control among the general public, facilitating source control from asymptomatic persons unknowingly transmitting virus. It is accepted that non-medical (community) masks are generally sufficient for this purpose, with members of the public having a lower transmission risk relative to that of HWs. However, certain designs of community masks are considered unfit for use (e.g., those containing respiratory exhalation valves do not 
offer source control) and use of medical grade PPE by the general population contributed to shortages [4].

In this context, many researchers are investigating the reprocessing and reuse of masks and filtering facepiece respirators (FFPs/FFRs), focusing on meeting regulatory standards and using readily available equipment present in hospitals. Decontamination is of paramount importance to any PPE re-use. Research in this area grew so fast in reaction to COVID-19 that literature reviews became available within one year [5-8]. Reprocessing or decontamination must ensure devices keep their original properties (e.g., filtering and breathability), functional integrity, shape and there must be no residual toxicity for the wearer $[9,10]$. Antimicrobial enhanced fabrics could be used to engineer masks and respirators allowing not only a longer lifespan of the mask, but also the possibility to exploit novel routes for mask decontamination. Antimicrobial systems can be broadly grouped into categories, as reported in a recent revision of the literature on PPE for health applications: [11] metal oxides and nanoparticles; salt compounds; graphene-based materials; quaternary ammonium compounds (QACs); N-halamine-based compounds; and naturally derived antimicrobial agents. Of these, nanoparticles, such as copper oxide, graphene oxide nanosheets [12] and plant extracts [13] have been investigated for decontamination methods.

There is no comprehensive systematic review available for masks fabricated with antimicrobial properties, their efficacy against bacteria or viruses or the possibility of reprocessing with the necessary durability and safety. Current standard methods for testing efficacy of antimicrobials are typically specific to the pathogen, i.e., bacterial (ISO 20743, AATCC TM100), viral (ISO 18184) or fungal (ISO 13629). General chemical safety assessments such as REACH chemical safety have limited application to modified fabrics for masks. Any recommendations concerning the development and production of PPE requires access to the best available evidence. Therefore, the present work provides a systematic review of the literature addressing antimicrobial materials and treatments for medical face masks, FFRs and community masks. The aim is to provide evidencebased recommendations on antimicrobial treatments for respirators and masks, especially regarding efficacy, reliability and safety to the wearer, and their possible role in facing the current pandemic and future healthcare crises.

\section{Methods}

\subsection{Search Strategy and Selection Criteria}

This study was conducted in accordance with the preferred reporting items for systematic reviews and meta-analyses (PRISMA) guidelines [14]. The protocol was designed prospectively and is available upon request. Studies were included if they met the following criteria: original peer-reviewed studies describing "augmented" masks by antimicrobial agents reporting at least one laboratory test in order to assess the efficacy.

MEDLINE and Embase databases were searched to identify studies from 1 January 2010 till 1 January 2021. Bibliographies of relevant articles were assessed as a secondary source of studies. The literature search was performed and verified by two independent reviewers using the index terms grouped in three categories: device (respirator OR mask OR filtering OR nonwoven OR fabric OR electro AND spun OR textile OR personal AND protection AND equipment), type of active augmentation (antimicrobial OR antiviral OR nanoparticles OR nanotechnology OR viricidal OR biocidal OR bactericidal OR inactivation) and organism affected (COVID-19 OR bioaerosol OR airborne OR coronavirus OR virus OR respiratory AND infections).

Two authors independently evaluated all retrieved studies against the eligibility criteria and divergent opinions were resolved, achieving consensus through discussion with a third author. Articles were excluded if there was not sufficient documentation. Reviews, duplicate publications and editorials were also excluded. 


\subsection{Data Analysis}

Data were extracted independently by two reviewers and entered into standardized spreadsheets. Any disagreement was resolved, achieving consensus via discussion with a third reviewer. The following data were extracted: type of article, publication year, type of substrate, type of antimicrobial system, integration methodology, viruses and/or bacteria tested and methods, antimicrobial efficacy results and secondary outcomes.

\subsection{Outcomes}

The main outcome was antimicrobial efficacy of antimicrobial treatments applied to PPE, measured by Logarithmic Reduction Value (LRV) of Colony Forming Units (CFU). This review also focused on methodological aspects, such as methods employed to assess antimicrobial efficacy, antimicrobial technology employed, how the treatment was integrated with the production process, which comparator was employed in each study, which pathogen was used and how it was applied to the PPE. Finally, a number of secondary outcomes were systematically investigated, aiming at assessing the impact of antimicrobial treatment on PPE fundamental properties, including: breathability; filtering capacity; reusability; impact on PPE cost/production; stability and durability of treatment; and safety for the wearer (e.g., toxicity via inhalation of antimicrobial treatment substances, skin irritations or respiratory inflammation).

\subsection{Risk of Bias}

Due to lack of standardized tools for assessing study results and risk of bias in this field, we employed previously developed objective assessment criteria $[10,15]$. This consisted of a predetermined evaluation matrix, containing information on study design, methodological consistency, population heterogeneity, sampling bias and selective reporting (Table S3 in Supplementary Materials). We adapted the original matrix, removing categories not relevant to this review. The assessment was made by two reviewers independently and divergences were overcome with consensus.

\subsection{Role of Funding Source}

The funder was involved in defining the scope of the work. Study design, data collection, data interpretation and report writing were completed independently of the funder.

\section{Results}

Searching MEDLINE and Embase yielded 2364 titles. After duplicate removal, 2116 titles/abstracts were screened, with 1982 excluded. Among the remaining 55 full-texts screened for compliance with the eligibility criteria, only 17 studies met the eligibility criteria and reported sufficient experimental results and methodological details for inclusion in the final analysis. Excluded full texts and reasons for exclusion are provided in Table S1. A flow chart representing the screening process is given in Figure 1. Table 1 contains a summary of the characteristics of the included studies covering three main areas: types of antimicrobial systems used, antimicrobial efficacy testing and results. A detailed account of all extracted information is provided in Table S2. Risk of bias was moderate or low in all studies, covering the following areas: study design, methodological consistency, population heterogeneity, sampling bias and selective reporting (Tables S3 and S4).

One study investigated commercially available antimicrobial FFRs [16], all other studies proposed novel antimicrobial systems [17-32]. A total of 15 studies concerned antimicrobial properties pertained through modification of pre-existing masks, filters or fabric substrates [16-22,24-27,29-32]. Two studies introduced antimicrobial compounds directly during fibre synthesis $[23,28]$. 


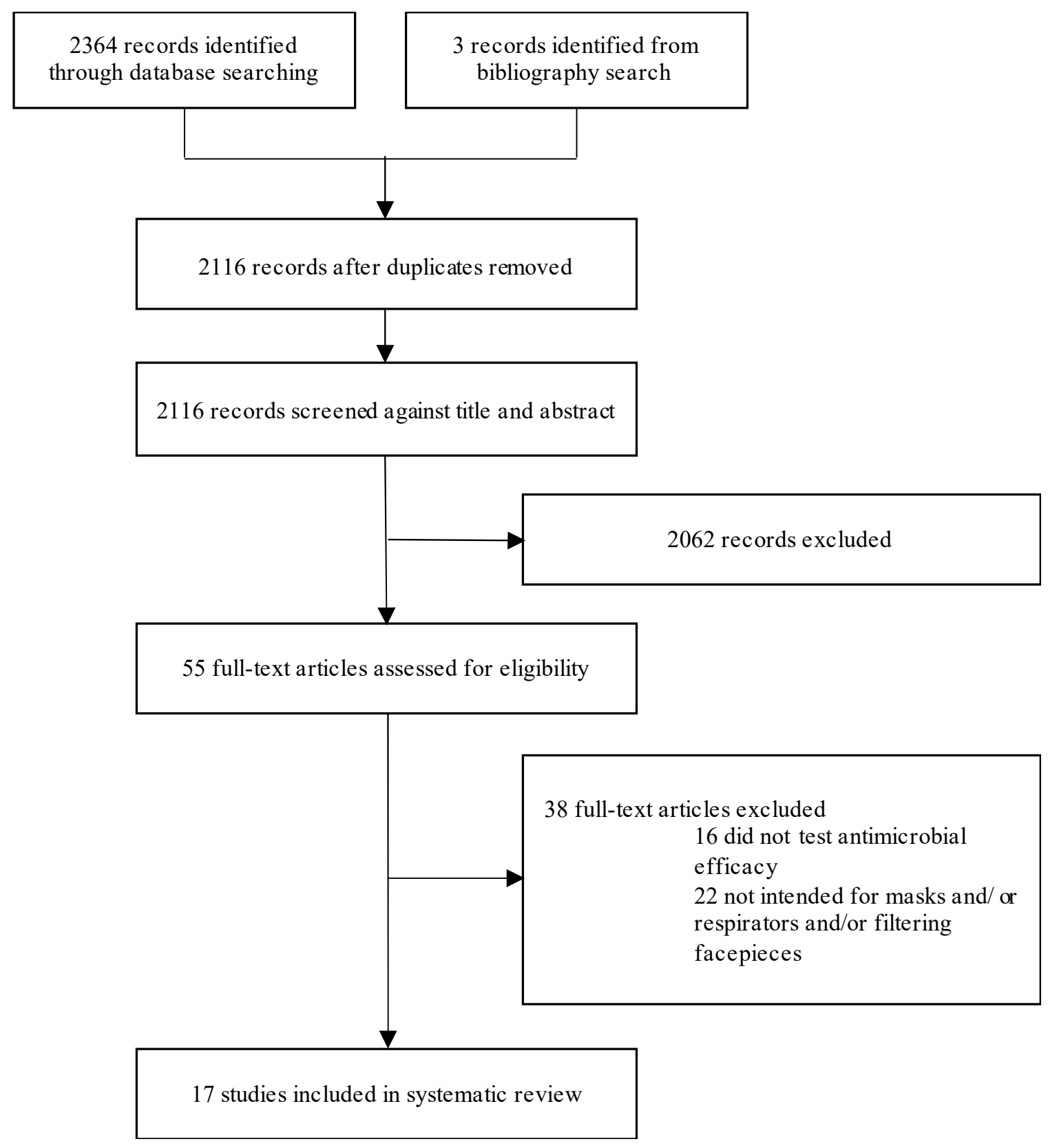

Figure 1. Study selection. PRISMA flow diagram of search and screening process.

In 16 studies laboratory pathogen strains were used to investigate antimicrobial efficacy using methods of: inoculation/incubation with the test system [17,18,21,24], bioaerosol challenge $[16,19,20,25,27,30,31]$ or both $[22,23,26,28,32]$. Only one clinical study, where bacteria were recovered from masks worn by volunteers, compared bacterial growth between worn/unworn masks [29]. Many studies compared antimicrobial activity towards Gram-negative and Gram-positive bacteria, most commonly investigated bacteria were by far Gram-negative Escherichia coli (E. coli) and Gram-positive Staphylococcus aureus (S. aureus) $[18,20-23,27,28]$. In order to measure activity against viruses, four studies used surrogates: three investigated the MS2 bacteriophage (MS2) [16,25,31] and one utilised extracellular vesicles as 'virus like particles' [26]. Five studies analysed viruses directly, employing a variety of influenza strains [17,30,32]. Only two studies investigated both bacteria and viruses $[25,26]$. No articles evaluated SARS-CoV-2, though viruses with comparable characteristics were considered. 
Table 1. Characteristics of included studies.

\begin{tabular}{|c|c|c|c|c|c|c|}
\hline & Substrate & Antimicrobial System & $\begin{array}{l}\text { Antimicrobial Efficacy } \\
\text { Testing Methods }\end{array}$ & $\begin{array}{l}\text { Pathogen(s) Used } \\
\text { in Testing }\end{array}$ & Comparators/Controls & Antimicrobial Efficacy Results \\
\hline Borkow et al. (2010) [17] & NIOSH N95 FFP & Copper oxide & $\begin{array}{l}\text { Bioaerosol challenge, } \\
\text { bacterial Filtration Efficacy }\end{array}$ & Viral & Untreated & $\begin{array}{l}\text { Significant, higher, direct contact } \\
\text { inactivation in test masks than control }\end{array}$ \\
\hline Zheng et al. (2016) [24] & NIOSH 3M N95 & Silver nanoparticles & $\begin{array}{l}\text { Bacterial growth } \\
\text { track, FESEM }\end{array}$ & Bacterial & Untreated & $\begin{array}{l}\text { Bacterial growth effectively inhibited. } \\
\text { FESEM: Few bacterial cells intact, debris } \\
\text { on treated surface }\end{array}$ \\
\hline Hiragond et al. (2018) [20] & Surgical face mask & Silver nanoparticles & Well diffusion assay & Bacterial & Untreated & $\begin{array}{l}\text { Inhibition zone of treated masks } \\
\text { significantly higher than control }\end{array}$ \\
\hline Rengasamy et al. (2010) [16] & 4 FFRs & $\begin{array}{l}\text { Silver-copper, } \\
\text { EvixO }_{3} \text {-Shield, Iodine, } \\
\text { Titanium dioxide }\end{array}$ & $\begin{array}{l}\text { Bioaerosol challenge. } \\
\text { Conditions: }(1) 22^{\circ} \mathrm{C} 30 \% \\
\text { RH for } 0,8,20 \mathrm{~h},(2) 37^{\circ} \mathrm{C} \\
80 \% \mathrm{RH} \text { for } 0,2,4 \mathrm{~h}\end{array}$ & Viral & Equivalent FFR & $\begin{array}{l}\text { Conditions: (1) no significant difference to } \\
\text { control (2) Silver-copper and } \\
\text { EvixO }_{3} \text {-Shield technology higher } \log _{10} \\
\text { reduction than control. Highest: } \\
\text { EvixO }{ }_{3} \text {-Shield technology }\end{array}$ \\
\hline Kumar et al. (2021) [26] & PP nonwoven & Copper nanoparticles & $\begin{array}{l}\text { Bacterial inoculation, } \\
\text { bacterial live dead assay, } \\
\text { bioaerosol challenge }\end{array}$ & Bacterial, viral & Untreated & $\begin{array}{l}\text { 4-log reduction in } E \text {. coli CFUs. Live/dead } \\
\text { assay indicates }>99.99 \% \text { reduction of } E \text {. coli. } \\
\text { VLP concentration decreased by } 2-3 \log \end{array}$ \\
\hline Lore et al. (2012) [25] & 4 NIOSH FFRs & Iodine-based & Bioaerosol challenges & Bacterial, viral & Equivalent FFRs & $\begin{array}{l}\text { No detectable antimicrobial properties in } \\
\text { test masks compared with conventional }\end{array}$ \\
\hline Rubino et al. (2020) [27] & Surgical masks & $\begin{array}{l}\text { Sodium chloride, potassium } \\
\text { sulphate potassium chloride }\end{array}$ & $\begin{array}{l}\text { Bioaerosol challenge, TEM, } \\
\text { in vivo mouse model }\end{array}$ & Bacterial & Untreated & $\begin{array}{l}\text { Physical damage to pathogens. } \\
\text { Time-dependent bacterial inactivation. } \\
\text { Infected mice lost less body weight and } \\
\text { had lower concentrations of lung bacteria } \\
\text { than those infected from control }\end{array}$ \\
\hline Quan et al. (2017) [30] & PP microfiber filter & Salt: Sodium chloride & $\begin{array}{l}\text { Bioaerosol filtration } \\
\text { efficiency, TEM }\end{array}$ & Viral & Untreated & $\begin{array}{l}\text { All challenge viruses were inactivated. } \\
\text { Evidence that this is due to hyperosmotic } \\
\text { stress on viral envelope }\end{array}$ \\
\hline Huang et al. (2020) [28] & Prototype & Inherent from LIG & $\begin{array}{l}\text { Bacterial live/dead assay, } \\
\text { SEM, bioaerosol collection }\end{array}$ & Bacterial & Commercial filter layer & $\begin{array}{c}\text { Antibacterial activity against } E \text {. coli: LIG: } \\
8157 \% \text {, ACF: } 2.00 \% \text {, MBF: } 9.13 \% \text {. SEM: } \\
\text { surface disruption bacteria. Aerosolized } \\
\text { bacterial efficiency } 88.89 \% \text {. E. coli viability: } \\
0.73 \log \text { reduction }\end{array}$ \\
\hline Tseng et al. (2006) [19] & Surgical mask & Goldshield 5 & Bioaerosol challenge & Bacterial & Untreated & $\begin{array}{c}>99.3 \% \text { antimicrobial efficiency against } \\
\text { bacteria on mask surface for all } \\
\text { test pathogens }\end{array}$ \\
\hline
\end{tabular}


Table 1. Cont.

\begin{tabular}{|c|c|c|c|c|c|c|}
\hline & Substrate & Antimicrobial System & $\begin{array}{l}\text { Antimicrobial Efficacy } \\
\text { Testing Methods }\end{array}$ & $\begin{array}{l}\text { Pathogen(s) Used } \\
\text { in Testing }\end{array}$ & Comparators/Controls & Antimicrobial Efficacy Results \\
\hline Xiong et al. (2021) [21] & Prototype & $\begin{array}{l}\text { QAC with boron } \\
\text { nitride nanoparticles }\end{array}$ & Incubation with bacteria & Bacterial & Untreated & $\begin{array}{l}\text { Antibacterial rate } 99.3 \% \text { for } E \text {. coli and } \\
96.1 \% \text { for S. aureus through 'contact } \\
\text { killing' mechanism }\end{array}$ \\
\hline Majchrzycka et al. (2012) [23] & PP nonwoven & Alkylammonium & $\begin{array}{l}\text { Incubation with } \\
\text { bacteria, bioaerosol } \\
\text { filtration efficiency }\end{array}$ & Bacterial & Untreated & $\begin{array}{c}\text { Biobentonite carrier: no antimicrobial } \\
\text { activity. Bioperlite carrier: inoculation and } \\
\text { bioaerosol tests } 95 \% \text { of } E \text {. coli, } 65.5 \% \text { of } S . \\
\text { aureus 'blocked' }\end{array}$ \\
\hline Demir et al. (2015) [22] & PP nonwoven & N-halamine: MC & $\begin{array}{l}\text { Incubation with bacteria, } \\
\text { bioaerosol challenge }\end{array}$ & Bacterial & Untreated & $\begin{array}{l}\text { No viable bacteria recovered from treated } \\
\text { fabrics or pores }\end{array}$ \\
\hline Duong-Quy (2020) [29] & Prototype & $\begin{array}{l}\text { Plectranthii amboinicii } \\
\text { plant oil extract }\end{array}$ & $\begin{array}{c}\text { Subject mask wearing: } \\
\text { Bacterial inhibition, aerobic } \\
\text { microbial test }\end{array}$ & Recovered bacteria & $\begin{array}{l}\text { Conventional surgical } \\
\text { mask }\end{array}$ & $\begin{array}{l}\text { Both conventional and LMC showed } \\
\text { sterile rings indicating both resistant to } \\
\text { bacteria, no significant difference in radius. } \\
\text { Antibacterial ability greater for aerobic } \\
\text { microbial testing }\end{array}$ \\
\hline Woo et al. (2012) [31] & Filters & DAS & Bioaerosol challenge & Viral & Untreated & $\begin{array}{l}\text { Very low survivability of MS2 on all filter } \\
\text { types treated with DAS. Higher } \\
\text { concentration of DAS associated with } \\
\text { lower survivability }\end{array}$ \\
\hline
\end{tabular}


A breakdown of the antimicrobial systems is given in Figure 2. Six studies utilized metal oxides and nanoparticles [16-18,20,24-26]. Borkow et al. [17] reported a copper oxide system applied to layers of an N95 FFR. A statistically significant contact inactivation of aerosolized human influenza A virus (H1N1) (2.88 log) and avian influenza virus (H9N2) ( $3.13 \mathrm{log}$ ) was granted relative to an untreated control, using a modified ASTM Method F 210101. Kumar et al. [26] coated polypropylene nonwoven fabrics of surgical masks with a composite of Shellac and copper nanoparticles. Their photocatalytic mechanism granted increased surface hydrophobicity and rapid temperature increase under solar illumination, achieving a four-log reduction of CFUs of E. coli relative to untreated fabric. A third study compared a NIOSH-approved N95 FFR with three manufacturer supplied prototype antimicrobial masks utilizing: silver-copper, EnvizO3-Shield technology (reactive oxygen species), $\mathrm{TiO}_{2}$ and iodine-activated resin [16]. Following bioaerosol challenge with droplet nuclei containing MS2, three fabrics $\left(\mathrm{TiO}_{2}\right.$ which could not be tested in those conditions) showed a higher $\log _{10}$ reduction than the N95, but only under conditions of $37{ }^{\circ} \mathrm{C} 80 \%$ $\mathrm{RH}$. Further, the reduction was only significant for the iodinated system ( $3.7 \mathrm{log}$ reduction of MS2). Lore et al. [25] also investigated an iodine-based antimicrobial treatment for respirators. However, no viability reduction was observed in this case, when challenged with three bioaerosols; MS2 bacteriophage virus, Bacillus atrophaeus vegetative bacteria and endospores. Other metal compounds included silver nitrate and titanium dioxide, which were found to grant a $100 \%$ reduction in viable E. coli and S. aureus recovered from the modified FFR, compared with an increase in viable bacteria from the untreated control FFR [18]. A silver based antimicrobial system was also investigated by Hiragond et al.; a commercially available mask augmented with colloidal silver [20]. Again, significant antibacterial activity (relative to untreated control) was seen against E. coli and S. aureus using a well-diffusion assay. A third study coated silver nanoparticles onto the filtering layer of a N95 FFR [24]. Bacterial growth (Pseudomonas aeruginosa and S. aureus) was strongly inhibited on coated fabric. Moreover, Field Emission Scanning Electron Microscopy (FE-SEM) showed minimal attachment of cells to treated fabric, no growth of bacteria colonies and cell debris, indicating cellular disruption due to the antimicrobial coating.

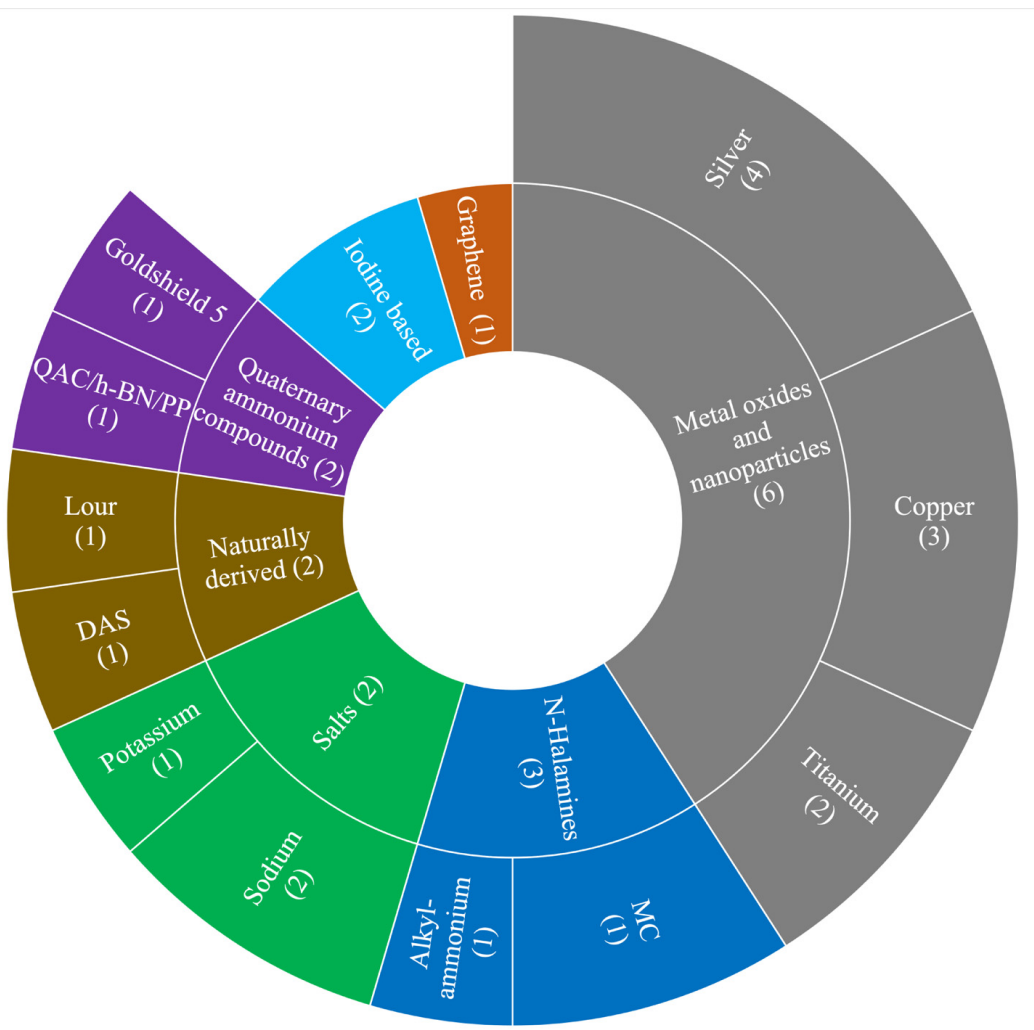

Figure 2. Classes of antimicrobial system. 
Internal segments denote the broad class of antimicrobial system and the corresponding number of studies, external segments display the specific compounds and the number of times they were employed across the study pool. Most antimicrobial systems were evaluated by only one study.

Antimicrobial properties of salt compounds were evaluated by two studies [27,30], in both studies transmission electron microscopy (TEM) highlighted structural damage and morphological changes in test pathogens, attributed to contact with the natural salt recrystallization process. Quan et al. applied a sodium chloride $(\mathrm{NaCl})$ salt coating to a surgical mask polypropylene filtering layer [30]. Aerosolized viral strains: H1N1, PR/34 H1N1 and VN/04 H5N1 applied to coated fabric were determined to be inactive by TEM, due to hyperosmotic stress upon the viral envelope. A second study also evaluated $\mathrm{NaCl}$, alongside potassium sulphate $\left(\mathrm{K}_{2} \mathrm{SO}_{4}\right)$ and potassium chloride $(\mathrm{KCl})$ [27]. Bacteria strains: Klebsiella pneumoniae, methicillin-resistant S. aureus, E. coli, Pseudomonas aeruginosa and Streptococcus pyogenes showed time-dependent inactivation for all salt coatings. Best performance was seen with a three-layer $\mathrm{NaCl}$ filter, granting a $4 \mathrm{log}$ reduction within $30 \mathrm{~min}$ of aerosol exposure. Bacterial inactivation was confirmed in vivo using a mouse infection model.

In one study, laser-induced graphene (LIG) was synthesized into fabric using Polyimide substrate [28]. The antibacterial properties were tested alongside commercial samples of activated carbon face masks (activated carbon fibre (ACF)) and surgical masks (meltblown fabric, MBF), by submerging in E. coli suspension. A CFU assay showed $0.73 \log$ reduction of $E$. coli after $8 \mathrm{~h}$. The antibacterial activity of LIG was found to be high, $81.57 \%$, compared to ACF (2.00\%), and MBF (9.13\%). Hydrophobic and hydrophilic LIG were compared and exhibited similar antibacterial activity. The authors propose this happens through different mechanisms; the former due to the abundant oxygen-containing functional groups such as $-\mathrm{COOH}$ and $-\mathrm{OH}$, that may cause loss of intracellular substances due to charge transfer, the latter due to dehydration.

Two QACs were evaluated [19,21]. Tseng et al. [19] applied Goldshield 5 (QAC based commercial detergent), to a surgical face mask. Over $99.3 \%$ antibacterial efficiency was seen when aerosolized bacteria (Acinetobacter baumannii, Enterococcus faecalis and S. aureus) challenged the mask surface. Xiong et al. [21] modified the PP layer of a surgical mask using QAC/ / Hexagonal Boron Nitride/PP (QAC/h-BN/PP), forming a nanocomposite, activated surface. E. coli and $S$. aureus were incubated with test fabric samples following standard methods (ISO 22196 and JIS Z 2801). Antimicrobial rates of the QAC/h-BN/PP samples were $99.3 \%$ (E. coli) and $96.1 \%$ (S. aureus), based on optical density of recovered bacteria. A so-called 'contact killing' mechanism was confirmed by zone-of-inhibition testing, i.e., the system did not release biocidal compounds.

N-halamine based biocidal systems were employed in three studies [22,23,32]. Majchrzycka et al. [23] used two inorganic carriers (bioperlite and biobentonite) to functionalize filtering nonwovens with an alkylammonium biocide (during fibre formation). Time dependent CFU assays showed biobentonite had low bacteriostatic and bactericidal activity towards E. coli and $S$. aureus. In contrast, bioperlite granted high biostatic and biocidal effects. Best performance was seen with 15/20\% bioperlite, after six hours of incubation (100\% reduction of $S$. aureus). Two studies investigated the N-halamine compound 1-Chloro-2,2,5,5-tetramethyl-4-imidazolidinone (MC) [22,32]. MC was coated onto meltblown nonwoven fabrics used for surgical face masks [22] and N95 respirators [22,32]. Both studies employed two testing methods: sandwich test and bioaerosol challenge (ASTM Method F 2101.01). Demir et al. [22] evaluated bacterial LRV following sandwich testing, finding 6.1log for E. coli (10 $\mathrm{min}$ ) and 6.26log for S. aureus (5 min). All bacteria collected from fabrics following aerosol exposure were inviable. Ren et al. [32] investigated MC's antiviral properties, sandwich testing showed complete inactivation of H1N1 virus (10 min). Even $0.1 \%$ w $/ \mathrm{MC}$ samples showed significant viral reduction. Against aerosolized H1N1, MC samples caused complete virus inactivation. 
Two studies investigated naturally derived antimicrobial agents [29,31]. Duong-Quy et al. [29] reported a novel face mask (Lamdong Medical College (LMC) mask) containing an antimicrobial agent derived from the leaf oil of Folium Plectranthii amboinicii (Lour), a traditional Vietnamese medicinal plant used to treat upper respiratory infections, bronchitis and gastrointestinal infections. The LMC mask and a four-layer activated carbon surgical mask (positive control) were worn by randomized volunteers, followed by laboratory analysis of recovered bacterial growth. Antibacterial activity of the LMC mask was not statistically different to the positive control. Woo et al. [31] investigated dialdehyde starch (DAS), seeking alternatives to aldehyde antimicrobials, which are highly toxic to humans. Commercial filters, such as two cellulose filters (CFs) commonly used for air cleaning and a polypropylene FFR (PF), were modified with DAS aqueous suspension at different concentrations. The antimicrobial assessment was made using a nebulized solution of MS2 bacteriophage and artificial saliva, to emulate aerosols produced from sneezing or coughing. Relative survivability (RS) of MS2 viruses on filters treated with different concentrations of DAS suspension showed a clear biocidal effect for all the filters, with RS decreasing with increasing concentration of DAS.

Table 2 contains a summary of the secondary outcomes addressed in the study pool. Three studies did not evaluate secondary outcomes $[20,24,32]$. The frequency of secondary outcomes investigated is given in Figure 3. No significant difference $[22,27,28]$ or very slight increase [26] in pressure drop across treated vs. untreated substrates was seen, taken to suggest acceptable levels of breathability. Woo et al. [31] compare similarly treated CF and PF substrates. CFs showed improvement in both pressure drop (lowered) and filtration efficiency (increased) when treated with DAS, with no improvement seen for PFs. A single study reported reduced filtration efficiency after coating of commercially available NIOSH FFRs (N95 and P95) [25]. Two studies found no change in filtration efficiency following antimicrobial treatment $[23,26]$, whereas salt coating increased filtration efficiency in one report [27]. Three studies evaluated toxicity $[17,18,29]$. One study evaluated particles released from the antimicrobial system, the authors demonstrated that copper eluted from their test mask was within the permissible exposure limit [17]. In contrast, Li et al. asked 20 volunteers to wear their nanoparticle-treated facemask, finding no reports of inflammation or itching after wearing. One study utilised a biomarker for respiratory inflammation to detect any inflammation potentially caused by wearing [29]. No formal cost analysis was offered, but several studies made statements about advantageous lowcost or easy production $[17,20]$. Durability/stability in terms of shelf life or storage was evaluated in four studies $[19,26,27,30]$. Tseng et al. found that their GS5 'decontamination effect' lasted a week after initial coating, concluding this would reduce cleaning costs and increase feasibility [19]. Kumar et al. claimed 'self-cleaning' properties (via nonwetting surface properties) reduced risk of exposure to pathogens on disposal [26]. Three studies investigated stability of the antimicrobial system under varied environmental conditions, to address storage considerations $[16,27,30]$. All systems were found to be stable to high temperature and humidity, taken to suggest safe long-term storage and reuse.

Fourteen studies considered secondary outcomes of which just three deal with a very important parameter which is safety for the wearer. 
Table 2. Secondary outcomes of included studies.

\begin{tabular}{|c|c|c|c|c|c|c|}
\hline & Safety & Breathability & Filtration Efficiency & Stability/Durability & Reusability & Cost/Production \\
\hline Borkow et al. (2010) [17] & $\begin{array}{l}\text { Copper eluted to air from } \\
\text { test mask in } 5 \mathrm{~h}: \\
0.467 \pm 0.47 \mathrm{pg}\left(<10^{5} \text { folds }\right. \\
\text { lower than permissible } \\
\text { exposure limit })\end{array}$ & & $\begin{array}{c}\text { Filtration efficiency } \\
\text { unaffected by treatment }\end{array}$ & & & $\begin{array}{l}\text { Statement: copper oxide } \\
\text { layer does not add } \\
\text { 'significant costs' }\end{array}$ \\
\hline Li et al. (2006) [18] & $\begin{array}{l}\text { No sign of skin } \\
\text { allergy/irritation after } 1 \mathrm{~h} \\
15 \text { min wearing } \\
(20 \text { volunteers })\end{array}$ & & & & & \\
\hline \multicolumn{7}{|l|}{ Zheng et al. (2016) [24] } \\
\hline Hiragond et al. (2018) [20] & & & & & & $\begin{array}{l}\text { Statement: starch is } \\
\text { abundant and low cost }\end{array}$ \\
\hline Rengasamy et al. (2010) [16] & & & & $\begin{array}{l}\text { Antiviral activity only } \\
\text { observed at high temp } \\
\text { and RH }\end{array}$ & & \\
\hline Kumar et al. (2021) [26] & & $\begin{array}{l}\text { Pressure drop similar for } \\
\text { treated mask at low velocity, } \\
\text { slight increase at } \\
\text { high velocity }\end{array}$ & $\begin{array}{c}\text { Filtration efficiency } \\
\text { unaffected by treatment }\end{array}$ & & $\begin{array}{c}\text { Rejection efficiency } \\
\text { unchanged after multiple } \\
\text { treatment cycles. } \\
\text { Nonwetting surface } \\
\text { properties grant } \\
\text { 'self-cleaning' ability }\end{array}$ & $\begin{array}{l}\text { Statement: reliable and } \\
\text { suitable for } \\
\text { industrial production }\end{array}$ \\
\hline Lore et al. (2012) [25] & & Elevated pressure drop & $\begin{array}{c}\text { Filtration efficiency } \\
\text { unaffected by treatment }\end{array}$ & & & \\
\hline Rubino et al. (2020) [27] & Statement: Salt types safe & $\begin{array}{l}\text { No significant rise in } \\
\text { pressure drop }\end{array}$ & $\begin{array}{l}\text { Filtration efficiency } \\
\text { improved by treatment }\end{array}$ & $\begin{array}{l}\text { Environmental stability: } \\
\text { stored at } 37^{\circ} \mathrm{C}, 70,80,90 \% \\
\text { RH for } 5 \text { days, antimicrobial } \\
\text { properties improved }\end{array}$ & $\begin{array}{l}\text { Statement: 'safe reusability } \\
\text { without further processing' }\end{array}$ & $\begin{array}{l}\text { Statement: salt types are } \\
\text { inexpensive; production } \\
\text { cost would be lower } \\
\text { compared with melt } \\
\text { blowing methods }\end{array}$ \\
\hline Quan et al. (2017) [30] & & & & $\begin{array}{l}\text { Environmental stability: } \\
37^{\circ} \mathrm{C} 70 \% \text { RH storage did } \\
\text { not affect efficacy }\end{array}$ & $\begin{array}{c}\text { Statement: reusable } \\
\text { at normal } \\
\text { environmental conditions }\end{array}$ & $\begin{array}{l}\text { Statement: treatment } \\
\text { is low-cost }\end{array}$ \\
\hline Huang et al. (2020) [28] & & $\begin{array}{l}\text { Pressure drop similar for } \\
\text { proposed system and } \\
\text { MBF standard }\end{array}$ & & & $\begin{array}{l}\text { 'Self-reporting of mask } \\
\text { conditions': through } \\
\text { response to moisture }\end{array}$ & $\begin{array}{l}\text { Statement: LIG can be } \\
\text { created using wide range of } \\
\text { carbon precursors allowing } \\
\text { easy supply }\end{array}$ \\
\hline
\end{tabular}


Table 2. Cont.

\begin{tabular}{|c|c|c|c|c|c|c|}
\hline & Safety & Breathability & Filtration Efficiency & Stability/Durability & Reusability & Cost/Production \\
\hline Tseng et al. (2006) [19] & & & $\begin{array}{c}\text { Filtration efficiency } \\
\text { unaffected by treatment }\end{array}$ & $\begin{array}{c}\text { 'Decontamination test' } \\
\text { challenging masks with } \\
\text { pathogens repeated } 1,2,4 \\
\text { or } 8 \text { days after } \\
\text { coating-Efficacy maintained }\end{array}$ & & \\
\hline Xiong et al. (2021) [21] & & $\begin{array}{l}\text { Air permeability decreased } \\
\text { with increasing } \\
\text { nanocomposite loading. } \\
\text { Acceptable at } 10 \% \\
(114.9 \mathrm{~mm} / \mathrm{s}) . \text { PM2.5 } \\
\text { removal efficiency }>90 \%\end{array}$ & & & $\begin{array}{l}\text { Thermal conductivity as } \\
\text { proxy for reusability: } \\
\text { maintained after } 5 \text { cycles of } \\
\text { reuse, PM2.5 removal } \\
\text { efficiency also unaffected }\end{array}$ & \\
\hline $\begin{array}{l}\text { Majchrzycka et al. } \\
\text { (2012) [23] }\end{array}$ & & & $\begin{array}{c}\text { Filtration efficiency } \\
\text { unaffected by treatment }\end{array}$ & & & $\begin{array}{l}\text { Industrial synthesis: Found } \\
\text { to be as effective } \\
\text { as laboratory }\end{array}$ \\
\hline Ren et al. (2018) [32] & $\begin{array}{l}\text { Statement: } \mathrm{MC} \text { has } \\
\text { low toxicity }\end{array}$ & & & & & $\begin{array}{l}\text { Statement: 'coating } \\
\text { procedure is } \\
\text { straightforward and } \\
\text { inexpensive' }\end{array}$ \\
\hline Demir et al. (2015) [22] & $\begin{array}{c}\text { Statement: 'no issues of } \\
\text { biocompatibility or toxicity' } \\
\text { (MC is not volatile and does } \\
\text { not emit chlorine gas) }\end{array}$ & $\begin{array}{l}\text { Air permeability not } \\
\text { affected by treatment }\end{array}$ & & $\begin{array}{l}\text { Antimicrobial system } \\
\text { deactivated by fluorescent } \\
\text { light—storage implications }\end{array}$ & & \\
\hline Duong-Quy (2020) [29] & $\begin{array}{l}\text { Nitric oxide as a biomarker } \\
\text { for respiratory } \\
\text { inflammation induced by } \\
\text { mask-lower in subjects } \\
\text { wearing test mask than } \\
\text { conventional mask }\end{array}$ & $\begin{array}{l}\text { Subjects reported higher } \\
\text { breathability of test mask } \\
\text { than conventional mask }\end{array}$ & & & & $\begin{array}{l}\text { Using natural compound; } \\
\text { renewable manufacturing }\end{array}$ \\
\hline Woo et al. (2012) [31] & $\begin{array}{l}\text { Statement: DAS does not } \\
\text { release toxic chemicals }\end{array}$ & $\begin{array}{l}\text { Pressure drop: air resistance } \\
\text { reduced in CFs but not PF }\end{array}$ & & & & \\
\hline
\end{tabular}

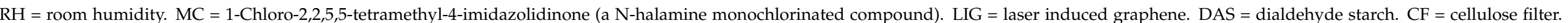

$\mathrm{PF}=$ polypropylene filter. 


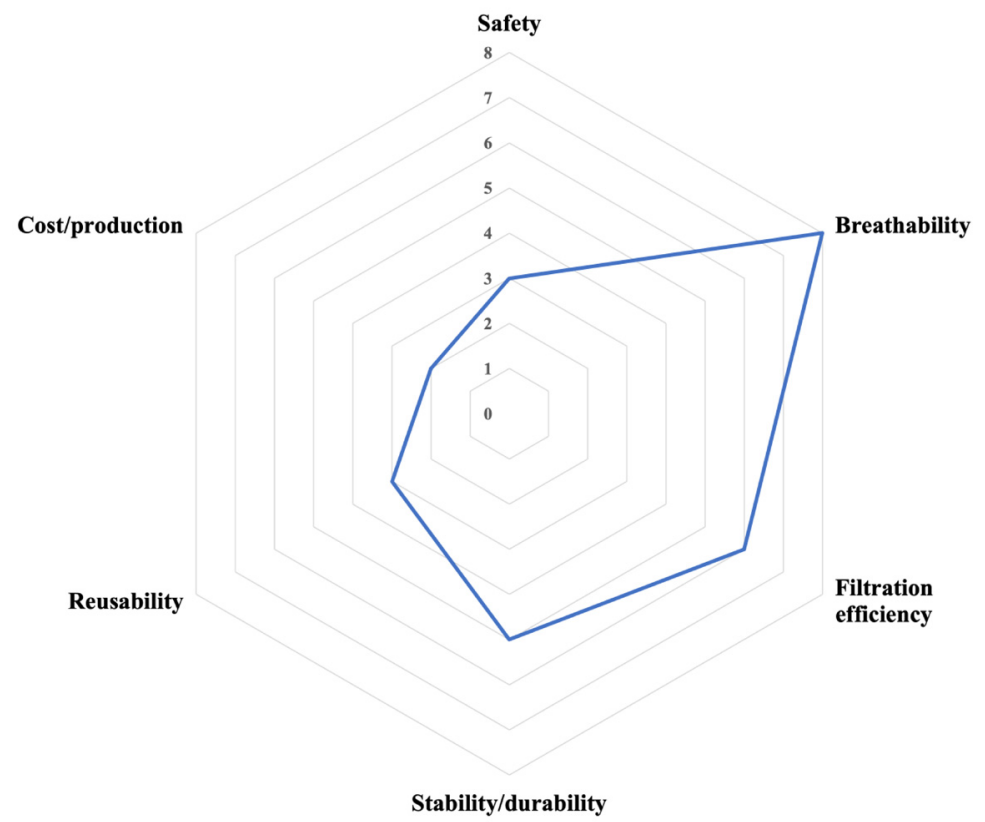

Figure 3. Number of studies considering other PPE properties beyond antimicrobial efficacy.

\section{Discussion}

The purpose of this literature review was to determine the efficacy of antimicrobial treatments applied to medical or community face masks. We focused on antimicrobial efficacy, methodological procedure and the impact of modifications on essential PPE properties. A total of 17 studies were included; of the excluded texts, 22 did not concern PPE, while 16 did not report antimicrobial efficacy. Overall, antimicrobial treatments were found to be effective. Yet, it is crucial to recognize the huge heterogeneity among studies, including technology employed, integration method, efficacy testing methods, challenge pathogens and control masks/fabrics. This is likely due to the fact that this is the first study systematically reviewing literature focusing on antimicrobial treatments for PPE. It is urgent to achieve standard methodology, in order to regulate community masks claiming to possess antimicrobial properties, becoming increasingly available on the market. Evidently, there is no standard method for assessing antimicrobial properties.

The very limited number of articles relating directly to antimicrobial systems for masks, relative to many focused on more general antimicrobial modified fabric, is noteworthy. We observed many articles investigating antimicrobial properties of augmented materials, postponing considerations of the final application to future research [33]. Other applications included skin wound care [34,35], water purification [36,37], air filters [38,39] and antimicrobial surfaces [40]. Unsurprisingly, most studies were published following outbreaks of epidemic-prone respiratory pathogens such as Avian influenza virus (H5N1) (2003) [41], H1N1 swine flu (2009/10) [42] and SARS-CoV-2 [43,44]. The majority of antimicrobial agents identified carry a body of evidence supporting their mechanism and utility [45]. The antimicrobial activity of copper and silver, especially in nanoparticle form, is well documented, including towards coronaviruses [46-48]. Indeed, N-halamines, graphene and QACs have proved effective against a broad spectrum of microorganisms, with long-term stability and durability [49-51]. The mechanism of graphene's antimicrobial action remains controversial, as discussed in Seifi et al.'s review of antibacterial properties of graphene. Several possible mechanisms were identified, including membrane stress, charge transfer, entrapment, oxidative stress, self-killing and photothermal, which may occur alone or in combination [51]. Photoactive chemicals producing reactive oxygen species are also considered effective and durable candidates for fabrication of antimicrobial materials [52,53]. 
The relative scarcity of research tackling antimicrobial systems for masks is compounded by a lack of shared procedures for evaluating efficacy and safety. Indeed, test methods were highly heterogenous amongst the identified studies, with antimicrobial assays varying from study to study (e.g., Sandwich test, ASTM Method F2101.01, CFU assay, zone of inhibition assay, etc.). This was also reflected in the challenge pathogens, varying greatly among bacteria, viruses and virus surrogates. Although all methods were scientifically valid, heterogeneity prevented direct comparison. In total, 16 of the 17 articles reported high efficacy of their augmented mask systems in either preventing proliferation or directly eliminating viral or bacterial pathogens. Of all systems considered, only one did not prove effective.

Interestingly, no studies attempted complete analysis of the mask system, covering fundamental properties of an airway protection device, i.e., filtering capacity, breathability (permeability to air, pressure drop), toxicity and longevity of the antimicrobial system and cost. Many studies evaluated some of these properties, while others provided antimicrobial efficacy results alone, leaving further analysis entirely to future work. An important aspect, safety of the product for the wearer, was addressed only in three studies, each with unique approaches. Only one study considered the possibility of reprocessing, authors claimed that their photoactive mask was able to 'self-sterilize' under solar irradiation, whilst maintaining its antiviral properties. Several articles discussed shelf life and reuse of their mask system, granted through the persistently active antimicrobial system, even when subject to variable humidity and temperature.

To improve homogeneity, considering the availability of community masks claiming antimicrobial efficacy, it is paramount that standards for testing antimicrobial efficacy and safety are created. Such standards should include well-defined results reporting, including appropriate comparators, considering not only the maximum value of LRV of CFU, but also reporting LRV at different time points, i.e., giving indications on the efficacy during wearing. Additionally, the maximum duration of the antimicrobial protection should always be addressed. The antimicrobial efficacy should be considered against viruses and bacteria in aerosolized and inoculated forms. All identified studies focused on reduction of transmission of airborne pathogens, none addressed transmission from contact with fluid secretions, i.e., touching of masks with contaminated hands, a major issue for non-professional users.

Moreover, safety is paramount, to avoid toxicity or adverse effects to the wearer, pre-existing standards must be met (e.g., REACH regulations from EU). Further, impact of modifications on key properties must be understood, namely filtration efficiency (e.g., ISO 21501-4; EN 14683:2019, EN 13274-7:2019; ASTM F2299) and breathing resistance (e.g., EN 14683:2019 (Annex C); ASTM D737; ISO 9237:1995). Lastly, treatment persistence should be considered and quantified (including limiting number of decontamination cycles in the case of reusable systems), including indications of storage/shelf life under normal conditions.

Supplementary Materials: The following are available online at https: / www.mdpi.com/article/ 10.3390/jcm10184066/s1, Table S1. A list of excluded studies and reasons for their exclusion, Table S2: Detailed information extracted from included studies, Table S3. Risk of bias tool, defining low, moderate and high risk of bias for each category, Table S4. Results of risk of bias assessment for each area and overall risk of bias score.

Author Contributions: F.B., L.P., U.B. and K.S., designed the study. F.B. and L.P. coordinated and supervised the study. F.B., U.B. and R.P. designed the data collection methodology. All authors acquired data, screened records, extracted data and assessed risk of bias. K.S. and F.B. wrote the original draft. All authors provided critical conceptual input; analysed and interpreted data; and critically revised and edited the manuscript. All authors have approved the final article. All authors have read and agreed to the published version of the manuscript.

Funding: World Health Organization: 2020/1079129-0. KS is funded by the MRC Doctoral Training Partnership [grant number MR/N014294/1]. 
Acknowledgments: This systematic review was commissioned and in part paid for by the World Health Organization (WHO) in the framework of the COVID-19 Blueprint IPC R\&D program, PPE Pillar, financed via a German Government donation. The authors alone are responsible for the views expressed in this article, which does not necessarily represent the decisions, policy or views of WHO.

Conflicts of Interest: The authors declare no conflict of interest.

\section{References}

1. Rowan, N.J.; Laffey, J.G. Unlocking the surge in demand for personal and protective equipment (PPE) and improvised face coverings arising from coronavirus disease (COVID-19) pandemic-Implications for efficacy, re-use and sustainable waste management. Sci. Total Environ. 2021, 752, 142259. [CrossRef]

2. World Health Organization. Rational Use of Personal Protective Equipment for Coronavirus Disease (COVID-19): Interim Guidance, 27 February 2020; World Health Organization: Geneva, Switzerland, 2020.

3. WHO. Advice on the Use of Masks in the Context of COVID-19: Interim Guidance, 5 June 2020; World Health Organization: Geneva, Switzerland, 2020.

4. Pecchia, L.; Piaggio, D.; Maccaro, A.; Formisano, C.; Iadanza, E. The Inadequacy of Regulatory Frameworks in Time of Crisis and in Low-Resource Settings: Personal Protective Equipment and COVID-19. Health Technol. 2020, 10, 1375-1383. [CrossRef]

5. Aljabo, A.; Mueller, E.; Abdul-Azeez, D.; Hoare, T.; Jain, A. Gravity steam reprocessing in healthcare facilities for the reuse of N95 respirators. J. Hosp. Infect. 2020, 106, 698-708. [CrossRef] [PubMed]

6. $\quad$ O'Hearn, K.; Gertsman, S.; Webster, R.; Tsampalieros, A.; Ng, R.; Gibson, J.; Sampson, M.; Sikora, L.; McNally, J.D. Efficacy and safety of disinfectants for decontamination of N95 and SN95 filtering facepiece respirators: A systematic review. J. Hosp. Infect. 2020, 106, 504-521. [CrossRef] [PubMed]

7. Gertsman, S.; Agarwal, A.; O’Hearn, K.; Webster, R.; Tsampalieros, A.; Barrowman, N.; Sampson, M.; Sikora, L.; Staykov, E.; $\mathrm{Ng}$, R.; et al. Microwave- and heat-based decontamination of N95 filtering facepiece respirators: A systematic review. J. Hosp. Infect. 2020, 106, 536-553. [CrossRef] [PubMed]

8. Pullangott, G.; Kannan, U.; Gayathri, S.; Kiran, D.V.; Maliyekkal, S.M. A comprehensive review on antimicrobial face masks: An emerging weapon in fighting pandemics. RSC Adv. 2021, 11, 6544-6576. [CrossRef]

9. Levine, C.; Grady, C.; Block, T.; Hurley, H.; Russo, R.; Peixoto, B.; Frees, A.; Ruiz, A.; Alland, D. Use, re-use or discard? Quantitatively defined variance in the functional integrity of N95 respirators following vaporized hydrogen peroxide decontamination during the COVID-19 pandemic. J. Hosp. Infect. 2021, 107, 50-56. [CrossRef]

10. Rodriguez-Martinez, C.E.; Sossa-Briceño, M.P.; Cortés, J.A. Decontamination and reuse of N95 filtering facemask respirators: A systematic review of the literature. Am. J. Infect. Control. 2020, 48, 1520-1532. [CrossRef]

11. Karim, N.; Afroj, S.; Lloyd, K.; Oaten, L.C.; Andreeva, D.V.; Carr, C.; Farmery, A.D.; Kim, I.-D.; Novoselov, K.S. Sustainable Personal Protective Clothing for Healthcare Applications: A Review. ACS Nano 2020, 14, 12313-12340. [CrossRef]

12. Ahmed, M.K.; Afifi, M.; Uskoković, V. Protecting healthcare workers during COVID-19 pandemic with nanotechnology: A protocol for a new device from Egypt. J. Infect. Public Health 2020, 13, 1243-1246. [CrossRef]

13. Chowdhury, M.A.; Shuvho, B.A.; Shahid, A.; Haque, A.M.; Kashem, M.A.; Lam, S.S.; Ong, H.C.; Uddin, A.; Mofijur, M. Prospect of biobased antiviral face mask to limit the coronavirus outbreak. Environ. Res. 2020, 192, 110294. [CrossRef]

14. Shamseer, L.; Moher, D.; Clarke, M.; Ghersi, D.; Liberati, A.; Petticrew, M.; Shekelle, P.; Stewart, L.A. Preferred reporting items for systematic review and meta-analysis protocols (PRISMA-P) 2015: Elaboration and explanation. BMJ Br. Med. J. 2015, 349 , g7647. [CrossRef]

15. Zorko, D.; Gertsman, S.; O’Hearn, K.; Timmerman, N.; Ambu-Ali, N.; Dinh, T.; Sampson, M.; Sikora, L.; McNally, J.; Choong, K. Decontamination interventions for the reuse of surgical mask personal protective equipment: A systematic review. J. Hosp. Infect. 2020, 106, 283-294. [CrossRef]

16. Rengasamy, S.; Fisher, E.; Shaffer, R.E. Evaluation of the survivability of MS2 viral aerosols deposited on filtering face piece respirator samples incorporating antimicrobial technologies. Am. J. Infect. Control 2010, 38, 9-17. [CrossRef] [PubMed]

17. Borkow, G.; Zhou, S.S.; Page, T.; Gabbay, J. A Novel Anti-Influenza Copper Oxide Containing Respiratory Face Mask. PLoS ONE 2010, 5, e11295. [CrossRef] [PubMed]

18. Li, Y.; Leung, P.; Yao, L.; Song, Q.; Newton, E. Antimicrobial effect of surgical masks coated with nanoparticles. J. Hosp. Infect. 2006, 62, 58-63. [CrossRef]

19. Tseng, C.-C.; Pan, Z.-M.; Chang, C.-H. Application of a quaternary ammonium agent on surgical face masks before use for pre-decontamination of nosocomial infection-related bioaerosols. Aerosol Sci. Technol. 2016, 50, 199-210. [CrossRef]

20. Hiragond, C.B.; Kshirsagar, A.; Dhapte, V.V.; Khanna, T.; Joshi, P.; More, P.V. Enhanced anti-microbial response of commercial face mask using colloidal silver nanoparticles. Vacuum 2018, 156, 475-482. [CrossRef]

21. Xiong, S.-W.; Fu, P.-G.; Zou, Q.; Chen, L.-Y.; Jiang, M.-Y.; Zhang, P.; Wang, Z.-G.; Cui, L.-S.; Guo, H.; Gai, J.-G. Heat Conduction and Antibacterial Hexagonal Boron Nitride/Polypropylene Nanocomposite Fibrous Membranes for Face Masks with Long-Time Wearing Performance. ACS Appl. Mater. Interfaces 2020, 13, 196-206. [CrossRef]

22. Demir, B.; Cerkez, I.; Worley, S.D.; Broughton, R.M.; Huang, T.-S. N-Halamine-Modified Antimicrobial Polypropylene Nonwoven Fabrics for Use against Airborne Bacteria. ACS Appl. Mater. Interfaces 2015, 7, 1752-1757. [CrossRef] 
23. Majchrzycka, K.; Gutarowska, B.; Brochocka, A.; Brycki, B. New Filtering Antimicrobial Nonwovens With Various Carriers for Biocides as Respiratory Protective Materials Against Bioaerosol. Int. J. Occup. Saf. Ergon. 2012, 18, 375-385. [CrossRef]

24. Zheng, C.R.; Li, S.; Ye, C.; Li, X.; Zhang, C.; Yu, X. Particulate Respirators Functionalized with Silver Nanoparticles Showed Excellent Real-Time Antimicrobial Effects against Pathogens. Environ. Sci. Technol. 2016, 50, 7144-7151. [CrossRef]

25. Lore, M.B.; Sebastian, J.M.; Brown, T.L.; Viner, A.S.; McCullough, N.V.; Hinrichs, S.H. Performance of Conventional and Antimicrobial-Treated Filtering Facepiece Respirators Challenged with Biological Aerosols. J. Occup. Environ. Hyg. 2012, 9, 69-80. [CrossRef] [PubMed]

26. Kumar, S.; Karmacharya, M.; Joshi, S.R.; Gulenko, O.; Park, J.; Kim, G.-H.; Cho, Y.-K. Photoactive Antiviral Face Mask with Self-Sterilization and Reusability. Nano Lett. 2020, 21, 337-343. [CrossRef]

27. Rubino, I.; Oh, E.; Han, S.; Kaleem, S.; Hornig, A.; Lee, S.H.; Kang, H.J.; Lee, D.H.; Chu, K.B.; Kumaran, S.; et al. Salt coatings functionalize inert membranes into high-performing filters against infectious respiratory diseases. Sci. Rep. 2020, $10,13875$. [CrossRef] [PubMed]

28. Huang, L.; Xu, S.; Wang, Z.; Xue, K.; Su, J.; Song, Y.; Chen, S.; Zhu, C.; Tang, B.Z.; Ye, R. Self-Reporting and Photothermal Enhanced Rapid Bacterial Killing on Laser-Induced Graphene Mask. ACS Nano 2020, 14, 12045-12053. [CrossRef]

29. Duong-Quy, S.; Ngo-Minh, X.; Tang-Le-Quynh, T.; Tang-Thi-Thao, T.; Nguyen-Quoc, B.; Le-Quang, K.; Tran-Thanh, D.; Doan-ThiQuynh, N.; Canty, E.; Do, T.; et al. The use of exhaled nitric oxide and peak expiratory flow to demonstrate improved breathability and antimicrobial properties of novel face mask made with sustainable filter paper and Folium Plectranthii amboinicii oil: Additional option for mask shortage during COVID-19 pandemic. Multidiscip. Respir. Med. 2020, 15, 664. [PubMed]

30. Quan, F.-S.; Rubino, I.; Lee, S.-H.; Koch, B.; Choi, H.-J. Universal and reusable virus deactivation system for respiratory protection. Sci. Rep. 2017, 7, 39956. [CrossRef]

31. Woo, M.-H.; Grippin, A.; Wu, C.-Y.; Baney, R.H. Use of dialdehyde starch treated filters for protection against airborne viruses. J. Aerosol Sci. 2012, 46, 77-82. [CrossRef] [PubMed]

32. Ren, T.; Dormitorio, T.V.; Qiao, M.; Huang, T.-S.; Weese, J. N-halamine incorporated antimicrobial nonwoven fabrics for use against avian influenza virus. Vet. Microbiol. 2018, 218, 78-83. [CrossRef]

33. Yin, X.; Zhang, J.; Xu, J.; Tian, M.; Li, L.; Tan, L.; Li, Z. Fast-acting and highly rechargeable antibacterial composite nanofibrous membrane for protective applications. Compos. Sci. Technol. 2020, 202, 108574. [CrossRef]

34. Wang, J.; Planz, V.; Vukosavljevic, B.; Windbergs, M. Multifunctional electrospun nanofibers for wound application-Novel insights into the control of drug release and antimicrobial activity. Eur. J. Pharm. Biopharm. 2018, 129, 175-183. [CrossRef]

35. Simões, D.; Miguel, S.A.P.; Ribeiro, M.; Coutinho, P.; Mendonça, A.; Correia, I.J. Recent advances on antimicrobial wound dressing: A review. Eur. J. Pharm. Biopharm. 2018, 127, 130-141. [CrossRef] [PubMed]

36. Ungur, G.; Hrůza, J. Modified polyurethane nanofibers as antibacterial filters for air and water purification. RSC Adv. 2017, 7, 49177-49187. [CrossRef]

37. Fahimirad, S.; Fahimirad, Z.; Sillanpää, M. Efficient removal of water bacteria and viruses using electrospun nanofibers. Sci. Total Environ. 2021, 751, 141673. [CrossRef] [PubMed]

38. Joe, Y.H.; Park, D.H.; Hwang, J. Evaluation of Ag nanoparticle coated air filter against aerosolized virus: Anti-viral efficiency with dust loading. J. Hazard. Mater. 2016, 301, 547-553. [CrossRef] [PubMed]

39. Jung, J.H.; Hwang, G.B.; Lee, J.E.; Bae, G.N. Preparation of Airborne Ag/CNT Hybrid Nanoparticles Using an Aerosol Process and Their Application to Antimicrobial Air Filtration. Langmuir 2011, 27, 10256-10264. [CrossRef]

40. Adlhart, C.; Verran, J.; Azevedo, N.; Olmez, H.; Keinänen-Toivola, M.M.; Gouveia, I.C.; Melo, L.F.; Crijns, F. Surface modifications for antimicrobial effects in the healthcare setting: A critical overview. J. Hosp. Infect. 2018, 99, 239-249. [CrossRef] [PubMed]

41. World Health Organization; Communicable Diseases Cluster. Avian Influenza: Assessing the Pandemic Threat; World Health Organization: Geneva, Switzerland, 2005.

42. WHO. WHO Recommendations for the Post-Pandemic Period 2010. Cited 2021. Available online: https://www.who.int/csr/ disease/swineflu/notes/briefing_20100810/en/ (accessed on 4 August 2021).

43. Sohrabi, C.; Alsafi, Z.; O’Neill, N.; Khan, M.; Kerwan, A.; Al-Jabir, A.; Iosifidis, C.; Agha, R. World Health Organization declares global emergency: A review of the 2019 novel coronavirus (COVID-19). Int. J. Surg. 2020, 76, 71-76. [CrossRef]

44. WHO. WHO Director-General's Opening Remarks at the Media Briefing on COVID-19-11 March 2020. Cited 2021. Available online: https:/ / www.who.int/director-general/speeches/detail/who-director-general-s-opening-remarks-at-the-mediabriefing-on-covid-19---11-march-2020 (accessed on 4 August 2021).

45. Imani, S.M.; Ladouceur, L.; Marshall, T.; Maclachlan, R.; Soleymani, L.; Didar, T.F. Antimicrobial Nanomaterials and Coatings: Current Mechanisms and Future Perspectives to Control the Spread of Viruses Including SARS-CoV-2. ACS Nano 2020, 14, 12341-12369. [CrossRef]

46. Cortes, A.A.; Zuñiga, J.M. The use of copper to help prevent transmission of SARS-coronavirus and influenza viruses. A general review. Diagn. Microbiol. Infect. Dis. 2020, 98, 115176. [CrossRef]

47. Han, J.; Chen, L.; Duan, S.-M.; Yang, Q.-X.; Yang, M.; Gao, C.; Zhang, B.-Y.; He, H.; Dong, X.-P. Efficient and quick inactivation of SARS coronavirus and other microbes exposed to the surfaces of some metal catalysts. Biomed. Environ. Sci. 2005, 18, 176-180.

48. Codita, I.; Caplan, D.M.; Drăgulescu, E.-C.; Lixandru, B.-E.; Coldea, I.L.; Dragomirescu, C.C.; Surdu-Bob, C.; Badulescu, M. Antimicrobial activity of copper and silver nanofilms on nosocomial bacterial species. Roum. Arch. Microbiol. Immunol. 2010, $69,204-212$. 
49. Hui, F.; Debiemme-Chouvy, C. Antimicrobial N-Halamine Polymers and Coatings: A Review of Their Synthesis, Characterization, and Applications. Biomacromolecules 2013, 14, 585-601. [CrossRef] [PubMed]

50. Yousefi, M.; Dadashpour, M.; Hejazi, M.; Hasanzadeh, M.; Behnam, B.; de la Guardia, M.; Shadjou, N.; Mokhtarzadeh, A. Anti-bacterial activity of graphene oxide as a new weapon nanomaterial to combat multidrug-resistance bacteria. Mater. Sci. Eng. C 2017, 74, 568-581. [CrossRef] [PubMed]

51. Seifi, T.; Kamali, A.R. Anti-pathogenic activity of graphene nanomaterials: A review. Colloids Surf. B Biointerfaces 2020, $199,111509$. [CrossRef]

52. Zhang, Z.; El-Moghazy, A.Y.; Wisuthiphaet, N.; Nitin, N.; Castillo, D.; Murphy, B.G.; Sun, G. Daylight-Induced Antibacterial and Antiviral Nanofibrous Membranes Containing Vitamin K Derivatives for Personal Protective Equipment. ACS Appl. Mater. Interfaces 2020, 12, 49416-49430. [CrossRef]

53. Li, Y.; Zhang, W.; Niu, J.; Chen, Y. Mechanism of Photogenerated Reactive Oxygen Species and Correlation with the Antibacterial Properties of Engineered Metal-Oxide Nanoparticles. ACS Nano 2012, 6, 5164-5173. [CrossRef] 